The Construction of British Chinese Educational Success: exploring the shifting discourses in educational debate, and their effects.

Becky Francis

Director, UCL Institute of Education, London, UK

b.francis@ucl.ac.uk

Ada Mau

School of Education, Communication and Society, King's College London, London, UK

ada.mau@kcl.ac.uk

Louise Archer

School of Education, Communication and Society, King's College London, London, UK

louise.archer@kcl.ac.uk 


\title{
The Construction of British Chinese Educational Success: exploring the shifting discourses in educational debate, and their effects.
}

\author{
The high achievement of British Chinese students in the British education system \\ is established in the official literature and has recently been subject to increased \\ attention and comment; albeit it remains the case that few studies have asked \\ students or their families about the factors contributing to their success. This \\ paper revisits findings from an earlier research project that investigated the extent \\ to which British Chinese students and their parents value education (and their \\ rationales), their experiences of British education, and the construction of British \\ Chinese students by their teachers. The study revealed the 'hidden racisms' \\ experienced by British Chinese students, the problematisation of their perceived \\ approaches to learning by British teachers in spite of their high attainment, and \\ the benefits, costs and consequences of their valuing of education. This article \\ contextualises these prior findings within more recent discourses and debates \\ around 'Chinese success', precipitated by increased policy attention to the \\ educational attainment of different groups of students, especially from low socio- \\ economic backgrounds. It argues that these discourses on one hand elevate \\ Chinese successes and teaching methods (in contrast to prior narratives), but on \\ the other they continue to exoticise and 'Other' the British Chinese, \\ misrecognising educational practices common among White middle class \\ parents.
}

Keywords: British Chinese; education; cultural capital; racialization; social mobility

\section{Introduction}

The educational attainment of Chinese-heritage students has been highlighted internationally by a range of academic and media vehicles (Miao and Davis 2015; Jerrim 2014; Chin 2015), and the success of East Asian nations, including Chinese jurisdictions (notably Hong Kong and Shanghai) in the international PISA rankings has also prompted media and educational attention (OECD 2013; BBC 2012; The Guardian 
2014; DfE 2014). In the UK education case, the British Chinese consistently stand as the highest attaining ethnic group (Pang 1999; DfEE 2001; Archer and Francis 2007; The Guardian 2014; DfE 2015). Nevertheless, in spite of sociological and educational attention to the relative attainment of other minority ethnic groups, the issue of British Chinese educational achievement had not been subject to research prior to the Economic and Social Research Council-funded study conducted by Francis and Archer in 2004 (see Francis and Archer 2005; Archer and Francis 2007). That study sought to explore British Chinese students' experiences of British education, and the possible reasons for (and costs of) their success; and the findings were widely published.

Since that time, awareness of Chinese educational attainment has grown due to an internationally-resonant discourse of Chinese 'hyper-success' in education, fuelled both by the OECD PISA studies and by the signification of the 'Tiger Mom' motif (Chua 2011). The 'model minority' label, which originated from the US, is typically used to describe academically successfully Asian heritage groups in Western societies, particularly those with ancestral ties to China, Korea, and Japan (Suzuki 1977, 1989; Lee 2009). This discourse intersects with, and is mutually sustained by, several other narratives producing 'The Chinese', including that of Chinese diligence, and that of a Chinese valuing of education. These latter discourses were identified within prior research (see e.g. Chau and Yu 2001; Parker 1998; Archer and Francis 2007): the notion of a 'Chinese valuing of education', especially, has been seen as an explanation for British Chinese educational high performance (Francis and Archer 2005, Archer and Francis 2005, 2006; Francis, Archer, and Mau 2009; BBC 2012); and as a means by which both Chinese and non-Chinese subjects construct and delineate 'The Chinese' as distinctive from Other ethnic groups (Francis and Archer 2005, 2006; Archer and Francis 2005, 2006). Francis and Archer (2005) explored the extent to which British 
Chinese young people and their parents construct education as valuable, and their reasoning, in an endeavour to shed some light on Chinese pupils' educational achievement.

This paper seeks to re-appraise the findings of that study in the context of developments on British Chinese attainment in the intervening decade. It attends especially to the implications of a range of contemporary discourses for the production of 'The Chinese' in the popular imagination some of which have developed further in the period since our prior study - and their effects. And in light of this analysis the paper goes on to consider questions precipitated for Western sociology and education by East-Asian mobilisation of practices facilitating high attainment.

\section{The educational 'hyper-success' of the Chinese}

As noted above, in the UK, British Chinese ${ }^{1}$ high attainment in compulsory education has been evident since Government and researchers first began to analyse attainment according to ethnicity (see e.g. Gillborn and Gipps 1996; DfEE 2001). While Taylor (1987) records few Chinese heritage students progressing on to Higher Education, this situation changed rapidly over the ensuing decade, with Gillborn and Gipps (1996) showing they were proportionally more likely than any other ethnic group in Britain to enter higher education (a situation that has extended to the present). They are the only minority ethnic group more likely than the White majority to attend a highly selective, Russell Group ${ }^{2}$ university (Francis, Archer, and Mau 2009). Research has also found that in spite of very significant attainment gaps according to socio-economic background and gender among the White majority, these gaps are far narrower in the British Chinese case (Gillborn and Gipps 1996; Francis and Archer 2005c; Archer and Francis 2006) - a significant point of interest given educational and policy attention to 
socio-economic gaps for attainment. Yet despite this educational success, it had not attracted the attention of educational researchers or policymakers until recently. Indeed, one of the very few studies to examine the educational approaches of the Chinese in Britain at the turn of the Century had not focused on attainment at all, but rather had focused on 'learning styles' of Chinese-heritage pupils; suggesting these to be unwholesomely deferent and conformist (Sham and Woodrow 1998; Woodrow and Sham 2001). As documented by Wong (1994), Chau and Yu (2000), Parker (2000) and Archer and Francis (2006), such stereotypical, deficit constructions echoed broader social discourses about the Chinese in Britain at that time - and, as we shall see, may extend to contemporary constructions of Chinese success.

Nevertheless, within a decade we have witnessed a discursive transformation from a silence on Chinese educational success to a media spray of allusion to it so regularised that the construct has become naturalised in the public imagination. The following British media comments are typical:

- 'China: The world's cleverest country?' (BBC 2012)

- "children in China achieve marks in maths up to 30 per cent higher than English pupils of the same age" (Mail Online 2014)

- Shanghai 15-year-olds are "three years ahead of their English counterparts in maths (Mail Online 2014);

- "Politicians and policymakers from the west, where children gain lower marks, are avidly studying the education systems of those countries* that regularly top the PISA international league tables in the hope of emulating their achievement" (*China and South Korea are cited. The Guardian 2014); 
- "I would bet my house that not one Chinese-British pupil, whether rich or poor, failed to get five good GCSEs. [...] Millions of failing British children could use a Tiger Mother in their tank" (Pearson, The Telegraph 2011).

- "children of immigrants from high-achieving east Asian countries are still twoand-a-half years ahead of their western peers by the time they are 15 , even when they are educated alongside them in western-style schools" (The Guardian 2014, citing Jerrim's research).

In 2015, the BBC even produced a television programme, 'Are Our Kids Tough Enough? Chinese School', described as a 'unique experiment' to compare the British and Chinese school systems. Five teachers from China educated 50 students in a Hampshire school using Chinese pedagogical methods for four weeks, and pupils in the 'Chinese School' outperformed the rest of their year group in a series of exams at the end of the experiment (BBC 2015). Likewise, 'Shanghai Maths' has recently been formally encouraged by the UK Government for practice in British schools (DfE, 2016).

Of course, on the face of it at least this appears a strongly celebratory discourse, which finally recognises British Chinese (and broader Chinese) success. The discourse of Chinese educational success also interrupts the previously hegemonic discursive construction of minority ethnic underachievement and 'failure' in the British Education system. Albeit, it may compound the pressure of high expectations from teachers and peers which British Chinese students reported finding oppressive (Archer and Francis 2005). But more than this, there are several notable features of the discourse. The first is, its positioning of the Chinese/British Chinese as distinctive, and different. This positioning is illustrated in the various newspaper quotes above. They are presented as 'super-achievers' - as different from 'us' - but also, as potentially excessive. Francis and Archer's prior study showed that the British Chinese were often constructed by 
teachers as achieving due to (excessive) diligence rather than 'natural ability' (Archer \& Francis 2005). And, as in the case of constructions of girls' achievement so welldocumented by feminist researchers, this perceived diligence tended to be problematised rather than celebrated. Indeed teacher constructions sometimes produced British Chinese students as automatons (Archer and Francis 2005): Too hard-working, too conformist, too pushed by parents. In other words, as Other. As outlined in the book, Understanding Minority Ethnic Achievement in Schools: race, class, gender and 'success' (Archer and Francis 2006), the Western ideal learner (Subject) is constructed by discursive binaries deeply embedded in the Western cultural vocabulary and imagination (Archer and Francis 2007). These position minority ethnic/female/working class bodies and practices as Other, deficit, and (in the case of achieving girls and minority ethnic boys) producing educational attainment in the wrong ways.

Especially, here and elsewhere we have added to the research which illustrates how achievement via diligence is pathologised in a society that constructs 'genius' as innate. Both pupils and teachers tend to produce 'brilliance' as natural and inherent, reproducing discourses prevalent in our wider historic and popular culture (Harding 1986, 1991; Clarricoates 1981, 1987; Walkerdine 1989, 1990; Francis et al, 2003). As these authors have argued, this construction is integrally gendered, 'raced' and classed, and bound up with enlightenment discourses that produce intellect and rationality as masculine, Western/White, and middle class. Albeit there is increasing recognition of the debilitating effects of the construction of 'ability' as innate ${ }^{3}$, nevertheless such constructions retain a powerful hegemony.

As our research, and recent work such as the documentary Tested (Chin 2015), illustrate, Chinese educational diligence tends to be constructed as excessive, and as 
producing high attainment in the wrong ways. We would argue this is because practices of hard work and exam preparation challenge, as well as being challenged by, the discourse of inherent ability and 'effortless achievement'. As we have seen, the discourse of effortless achievement maintains longstanding hegemony in the West, and disparages other modes of attainment. This can be illustrated by the assumptions on which selective entrance exams are premised: i.e., that selective schooling identifies those pupils with the highest innate ability (at whatever age) for more academic schooling. However, this is in turn viscerally challenged by the disproportionate success of Chinese and other East-Asian heritage groups in accessing selective education (see Jerrim 2014; Chin 2015; Ho, 2015) via practices of diligent preparation (see e.g. Zhou and Li 2003; Chin 2015). In other words, succeeding via the 'wrong methods' or 'gaming the system'. This produces an unease and distaste evident in the accounts of some non-Chinese commentators, illustrated in the documentary Tested (Chin 2015), for example, when a White journalist describes how much money Chinese parents spend on their children's test prep courses. On the one hand, these practices are challenging the essentialist notions on which Western concepts of educational 'meritocracy' are based. On the other, we should also like to suggest that these preparation and social capital-sharing practices adopted by some in the Chinese diasporic community reflect and illuminate practices standard among White middle class parents (see e.g. Ball 2003; Vincent and Ball 2001, 2006; Weis 2004; Francis and Hutchings, 2013). It is arguable that Amy Chua's book 'Battle Hymn of the Tiger Mother (2011) drew such media attention because it provoked a heady mix of envy, recognition, defensiveness and empathy in the (largely) White, middle class media commentators. 
The notion of Chinese educational diligence also relates closely to another aspect identified in our previous study (and by subsequent research) as explaining the relative educational success of the British Chinese: the valuing of education. The article alluded to above (Francis and Archer 2005) sought to investigate the extent to which British Chinese pupils and their parents view education as important and their rationales (for further details on the study, see Archer and Francis, 2007). Here we draw out elements underpinning this 'valuing', arguing that several which might be constructed as 'Tiger' perceptions/practices actually mirror well-documented White middle class practices used to secure educational attainment.

\section{British Chinese pupils' perceptions of the value of education}

\section{An instrumentalist approach}

The British Chinese young people's and parents' response to our question 'Is education important?' was universal. All said that it is. However, this is not to suggest that responses were uniform or unquestioning in this appraisal. What was noticeable, and what we drew out in the 2005 article, was the distinctive instrumental focus on credentialism for employment in the responses of British Chinese young people. Notably, this contrasted with the responses of the Chinese parent sample. Chinese parents in Britain had very diverse educational backgrounds (as most were first generation, post-Second World War migrants, often with very rudimentary education), and often provided explanations that expressed the intrinsic value of education. Pang (1999) lists 'future orientation' (as well as 'hard work') as one of the 'particular characteristics' displayed by the Chinese in Britain as a group. Some of our pupil respondents were quite specific in their articulation that if you work hard now you will reap the benefits in the future, demonstrating a willingness to defer pleasure in the 
present in order to ensure rewards later in life:

Because like you know, you think about it, you know, the people who actually make it without education is very low. The people do make it with education. So you know, it's better to work hard now then relax when you're older. Rather than to relax now and work hard when you're older. (Nick, male pupil, Albert Square School)

This deferment of pleasure is reminiscent of an attitude of the White, academic 'ear 'oles' in Willis' Learning to Labour (1977), and given that the British Chinese as a group are high-achieving in the British education system, it may be more than a coincidence that the two groups share this ethos. Moreover, in England educational instrumentalism is directly espoused and perpetuated by government policy: in this sense the student respondents' apparently credentialist position simply reflects a dominant (White middle class) model. Clearly, this instrumentalism, and deferment of pleasure, has been long associated with (White) middle-class practices in education (Willis 1977; Reay 1998; Vincent 2001; Vincent and Ball 2006).

There were other parallels between British Chinese practices and those of the White middle classes that were illuminated in British Chinese constructions of valuing education. For example, as well as sending children to weekend Chinese school (see Francis, Archer, and Mau 2009; Mau, Francis, and Archer 2009), a number of the parents volunteered that they were paying for extra tuition for their children outside school hours. This did not appear to be related to social class: some of the working class parents were paying for this extra provision (see Archer and Francis 2006). The increasing prevalence of such practices has been documented in the UK case (Ipsos Mori 2015), and the disproportionate uptake of additional academic tuition by more affluent social groups, and also by (not necessarily affluent) minority ethnic groups, has been identified (Francis and Hutchings 2013). 
The familiarity of out-of-school tuition, ‘shadow education' (Bray 2009), among British Chinese families is arguably a form of ethnic-based cultural capital, or 'ethnic capital' (Modood 2004; Zhou 2008). East Asian societies have a long established history of private supplementary tuition - from buxiban/cram schools in Taiwan to hagwon in Korea. A recent study shows that over half of Hong Kong's secondary students receive private supplementary tutoring, and in the last grade of secondary schooling the proportion exceeds 70\% (Bray 2013). Research from the US also shows the popularity of various forms of supplementary education in the communities of East Asian migrants such as Chinese and Koreans (Byun and Park 2012; Shrake 2010; Zhou 2008; Zhou and Kim 2006). Given the familiarity of supplementary education in their origin societies and the existence of such ethnic-based provisions in the UK (e.g. Chinese language schools, maths tutoring classes), British Chinese parents might be more likely and willing to seek extra support for their children's education, similar to their White middle-class counterparts.

A further parallel is the parental high expectations, and their manifestation in 'pushing' children academically. Our data showed that some pupils apparently received little discipline from parents regarding education, but many did discuss high levels of 'pressure' from parents regarding their educational achievement. Some of these portrayed it as positive, and others complained bitterly about it. Yet even where pupils complained about the pressure they were under, these complaints were often not straight-forward: they often acknowledged that parents were doing it 'for their own good', and supported this approach. As we pointed out in our article, there is a racist stereotype of minority ethnic groups such as Chinese or South Asians in Britain as 'oppressed by their home culture'. Extensive evidence shows that parental high expectation and surveillance of children's performance is routine in middle-class White 
families, and is a factor in the reproduction of educational success in these families (Reay 1998; Walkerdine, Lucey, and Melody 2001; Ball 2003; Weis 2004; Vincent and Ball 2006). This cultural capital is normalised as 'correct parenting', in spite of the financial, cultural and socio-economic capitals that underpin it (Reay 1998; Francis and Hutchings, 2013). Yet Western educationalists have often raised concerns about the impact of high expectation or 'pressure' on children in minority ethnic families concerning educational performance, presenting such pressure as oppressive or pathological (Siraj-Blatchford 1993; Basit 1997), while not recognising or problematising such parental 'pressure' in White middle-class families (Francis and Archer, 2005).

The mobilisation of social capital through networks, information sharing and communal (albeit, frequently, purchased) modes of support comprises a further notable similarity between the practices of Chinese-heritage groups and the White middle classes. Exemplars in the Chinese case are the information and preparation for Ivy League application provided by Chinese complementary schools in the US (Zhou and Li, 2003; Zhou and Kim, 2006), the additional prepping classes provided within the USChinese community for selective high school entrance and so on (Chin 2015), the additional tuition purchased to support attainment (Archer and Francis 2006), and practices of school 'choice' that result in Chinese-heritage pupils attending high quality and/or high attaining schools (see Jerrim 2014, for analysis in the Australian case). Such practices are all well-documented means by which the White middle classes promote their children's educational attainment (e.g. Kleitz et al. 2000; Reay and Ball 1998; Ball 2003; Vincent and Ball 2006; Francis and Hutchings 2013).

\section{Ethnically-specific discursive constructions}

Nevertheless, some discursive and material drivers underpinning the valuing of 
education were evidently ethnically-specific. For example, appreciation of education was often articulated in relation to migrant experiences and contexts:

\begin{abstract}
In China when it was the cultural revolution all the schools were closed down, I couldn't study. We all went up the mountains to settle, there was no chance to be educated, but now you can study and go to university and study whatever you want. (WingShan, parent).
\end{abstract}

Because when I was young my parents told me about the, always wanting to have education but they didn't have money to go to school. So, my parents said that it's really important that you put your education first. (Sally, pupil, Slater School for Girls)

Thus constructions of the value of education for children were frequently set against parental experiences of being deprived of education, and the wish to provide their children with educational opportunities they never had. As others have observed (e.g. in the case of British Pakistani families; Shah et al. 2010), migrant trajectories and resulting expectations can result in the bucking of generational reproductive trends in education identified by sociologists such as Bourdieu and Passeron (1977) (see Archer and Francis 2006, for discussion). Parents were also motivated by a desire to protect offspring from the gruelling work most had undertaken in the catering trade on arrival in Britain. As ShunHei observes, "I'm working in the kitchen; do I expect my son to work in the kitchen? Of course not. [...] No parent would want their child to do this job."

The belief in education as the method for social mobility is particularly important for Chinese diaspora and other minority migrant communities. Similarly to the situation for Asian-Americans (Sue and Okazaki 2009), education-based careers are perceived as a safe and viable means to maximise upward mobility due to discrimination and/or limitations for success in other areas (e.g. politics, sports, or arts) 
for British Chinese (Benton and Gomez 2008). A number of recent studies (Wood et al. 2009; Zwysen and Longhi 2016) confirm that ethnic minorities, including the British Chinese, continue to suffer from discrimination in the labour market in the UK. Therefore, parents and young people are more likely to believe that without a good education, their mobility and choices would be even more limited.

A further distinction was the construction of 'high valuing of education' as a specifically Chinese practice. The 'pushing' by Chinese parents of their children's educational application and success was frequently contrasted by many participants with the practices they saw among their White-British peers. For example, Amy (student, Salter School for Girls) lamented,

It's just their (Chinese parents') expectations are so much higher. And they just expect you to do better than other people. Like I have one friend who her parents doesn't really mind, just as long as she does alright and tries her hardest that's ok. My parents expect me to get the best grades. They expect me to be better than other people. And if I don't then they'll continuously start nagging at me to do better and everything, whereas white, I mean my friend's parents will be like, 'oh ok, you tried your best, make sure you try to improve it'. Well my parents will continuously be like 'try and practice your maths and get it better'. Like if I get a B, they'll be like, 'why didn't you get an A?'

We discussed how this 'pushing' may to some extent be a practical response from parents impeded from other ways of supporting their children given their lack of educational experience and their often long working hours: stress on high expectations for behaviour and achievement at school comprises a strategic response to an acknowledged lack of alternative forms of cultural and social capital (Archer and Francis, 2006). But beyond this, as Battle Hymn of the Tiger Mother (Chua 2011) so vividly illustrates, the notion of high value of education as a feature of Chinese culture 
(see Taylor 1987; Parker 1998; Pang 1999) is used to produce the Chinese as culturally distinctive from other ethnic groups. This 'special' valuing of education was acknowledged and articulated with pride by some of the parents in our study, leading us to suggest that this notion was being drawn on to construct a diasporic cultural boundary for the first and second generation Chinese in Britain (Parker 1998; Francis and Archer 2005; Francis and Archer 2006). A construction of attributes in racialised boundaries was evident in responses; a Chinese 'we' who value education positioned against an English (White) Other who do not.

This also relates somewhat to the issue of 'face' as a motivator for educational attainment: some students described how high exam grades, entrance to the rights schools and universities comprise key currency in 'giving good face' in competitive interaction with other Chinese-heritage families (Woodrow and Sham 2001; Francis and Archer 2005; Chin 2015). In other words, the respect and status of academic achievements and professional careers would confer on the whole family, not just the individual young person; something which is observed in British South Asian communities as well (Shah et al. 2010). These competitive practices may encourage, and sometimes pressure, both the parents and children to invest effort into education and attainment outcomes.

\section{Discussion}

We have argued that, while there are clearly some ethnically-distinct practices promoting the educational attainment of British Chinese pupils, due to migrant experiences and circumstances, and the construction of discourses and identities in response to disaporic contexts, many of these British Chinese practices mirror those adopted by the White middle class. In this sense, it is arguable that many British 
Chinese educational practices hold 'exchange value' (cf Bourdieu 1990) in currencies of social and cultural capital that enable the production of educational success in similar ways to the White elite. In spite of their often contrasting financial resources, they mobilise similar methods, across similar routes. This is highly distinctive, given the findings about many minority ethnic parents possessing the 'wrong cultural currency' (Reay 1998) to realise their high aspirations for their offspring, via their interaction with the British education system. Given teachers' frequent constructions of British Chinese students as inappropriately diligent and conformist, and their parents as problematically pushy (Ran 2001; Archer and Francis 2006; Mau 2014), it appears that the British Chinese are able to exchange their social and cultural capital to successfully "play the game' of educational choice and application to realise achievement, in spite of this misrecognition of their 'currency'.

On the other hand, this success is not without cost. Costs for British Chinese families are material and psychic/emotional (Archer and Francis 2006), but the increasing visibility of British Chinese (and broader Chinese) educational attainment also exacerbates longstanding racialised narratives. Wong (2015) argues that the 'model minority' discourse can encourage and facilitate the high-achieving learner identity among British Chinese (and Indian heritage) students, for example, through having higher expectations from families and teachers. However, the psychological pressure to succeed can create stress and a sense of insecurity (e.g. worries over being 'never good enough'), and the needs of British Chinese students who do not fit the model minority stereotype (e.g. average or below-average achievers) could be neglected (ibid.).

The 'positive' stereotypes (e.g. high achieving, hard-working, problem-free) of British Chinese students conceal the challenges and inequalities they experience at school and elsewhere. Evidence (e.g. Archer and Francis 2006; Mau 2014; Thomas 
2015) shows that British Chinese young people continue to regularly suffer from both traditional forms of racism (e.g. explicit verbal and physical abuse) and subtle forms of cultural exoticisation (e.g. covert forms of racism and micro-aggression). Furthermore, many in the British Chinese community believe these issues are not being taken seriously by the authorities (e.g. schools, police) (Adamson et al. 2009). Unlike in North America or Australia, where the Chinese population represent a sizeable number within the larger pan-Asian group, the British Chinese population is small numerically and also geographically spread around the UK (due to the historic scattered settlement pattern necessitated by the catering trade), which often makes them the 'minority within the minority'. The absence of co-ethnic support could make negative race or culture-based experiences more isolating and alienating.

Additionally, research (e.g. Benton and Gomez 2008; Wong 2015) shows that British Chinese young people's career pathways tend to concentrate on a list of 'safe', high-status professions (e.g. law, business, medicine), which helps minimise discrimination and the 'ethnic penalty'. This social mobility strategy can provide social prestige and security to young people and their families. However, on the other hand, the lack of representation in other sectors of society, particularly mainstream British public culture (e.g. politics, media) (Chan 2010), further perpetuate the 'model minority' stereotype as well as the invisibility of the unmet needs of the community.

As we argued at the beginning, these discourses characterise 'The Chinese' as homogeneous, and as different from others (and/or from the White majority, constructed as 'us'). After all, we need to acknowledge that the category of 'Chinese' is itself complex. The UK Chinese population represents a diverse range of migration trajectories, as well as cultural, linguistic, socioeconomic, and generational differences, with people descended from Hong Kong, China, Southeast Asia, the Caribbean, and 
elsewhere. However, the 'model minority' construct is a racist discourse which disregards the population's complexity and essentialises Chineseness against Whiteness (Yeh 2014), as well as 'problem' minorities, e.g. African Americans (San Juan 1999; Lee 2009) and British Black Caribbean students. Scholars (Okihiro 1994; Benton and Gomez 2008; Yeh 2014) have argued that in fact the model minority discourse reproduces the 'Yellow Peril' image by marginalising Chinese yet again as threatening (e.g. educational 'hyper-success', 'gaming the system' into elite educational institutions and professions) and inhuman (e.g. working too hard, insular to racism and other forms of hardship) - the unassimilable, 'Oriental' 'Other' .

This production of 'The Chinese' as 'Other' in turn facilitates narratives of excess and abnormality. As we have shown, while such narratives are directed at the British Chinese, the White middle class practices of educational reproduction which those of the British Chinese so closely reflect escape attention; rather being normalised as the appropriate and desirable practices of respectable, suitably aspirational parents (Reay 2006). It is vital to maintain attention to such discursive silences and the (gendered, classed and 'raced') construction of the 'normal' in educational attainment, and to the discursive constructions of minority ethnic individuals and groups as Other. Meanwhile, the British Chinese case productively complicates sociological theories of class reproduction, and challenges longstanding Western educationalist constructions of 'innate ability' and 'the ideal student'.

Furthermore, British Chinese academic success also challenges the debates of meritocracy in the British education system and society. Education has been promoted as an important route to social mobility and economic prosperity in UK government policy since post-WWII period, reflected by policy interventions from selective grammar schooling, to comprehensivisation, to widening participation in higher 
education. Despite their overall strong achievement at school/pre-university level, British Chinese 'success' is in fact more mixed and segmented in higher education and employment.

Evidence shows that ethnic minorities, including high-performing British Chinese and Indian students, are less likely to be offered places at elite, highly selective UK universities than White applicants, even when they have the same grades (Boliver 2016). Similar to other British students from minority ethnic groups, Chinese students $(63.9 \%)$ are less likely to than White students $(73.2 \%)$ to receive top degrees awards (a First or 2:1 classification) at university (data from 2012/13, ECU 2016). As discussed earlier in this paper, the employment 'success' of British Chinese is segmented. Serious questions need to be asked about why the outstanding achievements at school level do not translate directly into university level and the labour market, especially given policies have been focusing on increasing social mobility through education. While British Chinese families might have been able to mobilise various forms of capital to further their children's educational attainment at school, similar to White middle class families, it is unclear whether this currency is similarly transferable in these later stages. When the 'game' (Bourdieu, 1999) is no longer just about credentials (Tomlinson 2008) but also soft skills and employability, gained through extra-curricular activities such as internships and networking, White middle class advantage appears to be maintained as they are better positioned to meet these new demands (Bathmakera, Ingramb and Waller 2013).

Hence the 'success' of the British Chinese in compulsory schooling offers a significant case to examine both the socio-cultural practices that enable educational success and potential mobility, and the reproduction of social inequalities in education and beyond. Analysis of the discursive 'Othering' and exoticisation of the educational 
practices of the British Chinese and Chinese generally by Western commentators sheds light on the classed cultural practices of the White majority, and of Western assumptions about the ideal learner and the (innate) nature of educational 'ability'. However, while it is important to recognise the educational success of many British Chinese, it is also vital we attend also to destination data, in order to track and articulate the continuing inequalities faced by this group of young people.

Acknowledgements

We would like to express our thanks to all reviewers and editors who have provided comments and suggestions for the revision of the manuscript.

${ }^{1}$ The British Chinese population is diverse and heterogeneous, representing a range of origins, language, and migration histories. At the time of this study, the majority of the student respondents were from second-generation British Chinese whose parents are from Hong Kong. In the last decade, the majority of new Chinese migrants in the UK have come from Mainland China. There is also a smaller but significant portion of the British Chinese community with links to Malaysia, Singapore, and Vietnam.

${ }^{2}$ The Russell Group represents 24 of the most prestigious, research-intensive universities in the UK, including University of Oxford and University of Cambridge.

${ }^{3}$ See e.g. Dweck's work on Mindset (e.g. 2012), or the research showing that ability at maths is frequently viewed as innate in the UK (Hodgen, 2011) 
References

Adamson, S., B. Cole, G. Craig, B. Hussain, L. Smith, I. Law, C. Lau, C.K. Chan, T. Cheung. 2009. Hidden from public view? : Racism against the UK Chinese population. London : The Monitoring Group.

Archer, L. and B. Francis. 2005. "They Never Go Off the Rails Like Other Groups: Teachers' constructions of British-Chinese pupils' gender identities and approaches to learning." British Journal of Sociology of Education 26 (1): 165-182. doi:10.1080/0142569042000294156

Archer, L. and B. Francis. 2006. "Challenging classes? Exploring the role of social class within the identities and achievement of British Chinese pupils." Sociology 40 (1): 2949. doi: 10.1080/03075070309290

Archer, L. and B. Francis. 2007. Understanding Minority Ethnic Achievement: Race, gender, class and 'success'. London: Routledge.

Ball, S. 2003. Class Strategies and the Education Market: the middle classes and social advantage. London: RoutledgeFalmer.

Ball, S. and C. Vincent. 1998. "'I heard it on the grapevine': 'hot' knowledge and school choice." British Journal of Sociology of Education 19 (3): 377-400

Bathmaker, A., N. Ingram, and R. Waller. 2013. "Higher education, social class and the mobilisation of capitals: recognising and playing the game." British Journal of Sociology of Education 34 (5): 723-743. doi: 10.1080/01425692.2013.816041

BBC. 2015. Are Our Kids Tough Enough? Chinese School. Television (3 episodes). BBC Two, August 4-18. 
Basit, T. 1997. "I want more freedom, but not too much': British Muslim girls and the dynamism of family values." Gender and Education 9 (4): 425-439.

Benton, G. and E. T. Gomez. 2008. The Chinese in Britain, 1800-Present. London: Palgrave Macmillan.

Boliver, V. 2016. "Exploring ethnic inequalities in admission to Russell Group Universities.” Sociology 50 (2): 247-266. doi: 10.1177/0038038515575859

Bourdieu, P. 1990. The Logic of Practice. Cambridge: Polity Press.

Bourdieu, P. 1999. Weight of the World: Social Suffering in Contemporary Society. Cambridge: Polity.

Bourdieu, P. and J. Passeron. 1977. Reproduction in Education, Society and Culture. London: Sage.

Bray, M. 2009. Confronting the Shadow Education System: What Government Policies for What Private Tutoring? Paris: UNESCO International Institute for Educational Planning (IIEP).

Bray, M. 2013. "Benefits and Tensions of Shadow Education: Comparative Perspectives on the Roles and Impact of Private Supplementary Tutoring in the Lives of Hong Kong Students." Journal of International and Comparative Education 2 (1): 1830. doi:10.14425/00.45.72

Burman, E. and I. Parker. eds. 1993. Discourse Analytical Research, London: Routledge.

Byun, S. and H. Park. 2012. "The Academic Success of East Asian American Youth: The Role of Shadow Education.” Sociology of Education 85(1): 40-60. doi:10.1177/0038040711417009 
Chan, B. 2010. "Discussion paper on the UK Chinese Community and Migration." Prepared for Min Quan, Conference on the Representation, Rights and Migration of the UK Chinese Community, House of Commons, London, March 16.

Chau, R. and S. Yu. 2001. "Social Exclusion of Chinese People in Britain", Critical Social Policy 21 (1): 103-125.

Chin, C. 2015. dir. and prod. Tested. Motion picture. Bull and Monkey. New York.

Chua, Amy. 2011. Battle Hymn of the Tiger Mother. London: Penguin.

Clarricoates, K. 1981. “The experience of patriarchal schooling.” Interchange 12 (2/3): 185-206.

Clarricoates, K. 1987. "Child culture at school: a clash between gendered worlds.” In Children and Their Primary Schools, edited by A. Pollar, 188-206. Lewes: Palmer.

Coughlan, S. 2012. “China: The world's cleverest country?” The BBC, May 9.

\section{http://www.bbc.co.uk/news/business-17585201}

DfE (Department for Education). 2014. "Network of 32 maths hubs across England aims to raise standards." Press release. July 1.

https:/www.gov.uk/government/news/network-of-32-maths-hubs-across-englandaims-to-raise-standards

DfE (Department for Education). 2015. "Statistical First Release: GCSE and equivalent attainment by pupil characteristics, 2013 to 2014 (Revised).” DfE. January 29.

DfE (Department for Education). 2016. "South Asian method of teaching maths to be rolled out in schools." Press release. July 12.

https://www.gov.uk/government/news/south-asian-method-of-teaching-maths-to-be- 
rolled-out-in-schools

DfEE (Department for Education And Employment) 2001. "Black and Indian Students: improvement in GCSE results." Press notice 2001/0033.

DfEE (Department for Education And Employment) 2001b. Statistics in Education: Schools in England, 2000 London: DfEE.

ECU (Equality Challenge Unit). 2016. "Degree attainment gaps" ECU. Accessed July 27 2016. http://www.ecu.ac.uk/guidance-resources/student-recruitment-retentionattainment/student-attainment/degree-attainment-gaps/

Francis, B. (1999a) "An investigation of the discourses children draw on in their constructions of gender.” Journal of Applied Social Psychology 29 (2): 300-316.

Francis, B. (1999b) "You Can Never Get Too Much Education: the discourses used by secondary school students in their discussions of post-compulsory education." Research in Post-Compulsory Education 4 (3 ): 305-319.

Francis, B. and L. Archer. 2005. 'British-Chinese Pupils' and Parents' Constructions of the Value of Education." British Educational Research Journal 31 (1): 89-107. doi:10.1080/0141192052000310047

Francis, B. and L. Archer. 2005b. 'British-Chinese Pupils' Constructions of Gender and Learning." Oxford Review of Education 31 (3): 497-515. doi:10.1080/03054980500355385

Francis, B., L. Archer, and A. Mau. 2009. "Language as Capital, or Language as Identity? Chinese complementary school pupils' perspectives on the purposes and benefits of complementary schools." British Educational Research Journal 35 (4): 519538. doi: 10.1080/01411920802044586 
Francis, B. and M. Hutchings. 2013. Parent Power? London: The Sutton Trust. Francis, B., B. Read, J. Robson, and L. Melling. 2003. "Lecturers' constructions of gender and undergraduate writing." British Journal of Sociology of Education 24 (3): 357-373.

Gillborn, D. and C. Gipps. 1996. Recent Research on the Achievement of Ethnic Minority Pupils London: HMSO.

Harding, S. 1986. The Science Question in Feminism. Milton Keynes: Open University Press.

Harding, S. 1991. Whose Science? Whose Knowledge? Buckingham: Open University Press.

Ho, C. 2015. "The new meritocracy or over-schooled robots? Public attitudes on AsianAustralian education cultures." Paper presented at Asian Migration and Education Cultures International Workshop, University of Western Sydney, December 9-10.

Ipsos Mori. 2015. "Private tuition polling 2015" The Sutton Trust, September 4. http://www.suttontrust.com/researcharchive/private-tuition-polling-2015/

Jerrim, J. 2014. "Why do East Asian children perform so well in PISA? An investigation of Western-born children of East Asian descent." Department of Quantitative Social Science, Working Paper No. 14-16, Institute of Education, University of London.

Kleitz, B., G. R. Weiher, K. Tedin, and R. Matland. 2000. "Choices, charter schools, and household preferences.” Social Science Quarterly, 81 (3): 846-854.

Lee, S. J. (2009). Unraveling the 'model minority' stereotype: Listening to Asian American youth. 2nd ed. New York, NY: Teachers College Press. 
Mau, A., B. Francis, and L. Archer. 2009. "Mapping politics and pedagogy: understanding the population and practices of Chinese complementary schools in England." Ethnography and Education 4 (1): 17-36. doi: 10.1080/17457820802703473

Mau, A. 2014. "Beyond Kung Fu and takeaway: Negotiation of British Chinese identities in schools." In Advancing race and ethnicity within education, edited by Richard Race and Vini Lander, 111-127. Basingstoke: Palgrave Macmillan.

Miao, Z. and D. Reynolds. 2015. "Uncovering classroom-level factors for the performance gap in mathematics between England and China: a synthesis of results and findings from an international teacher effectiveness study." Paper presented at the British Educational Research Association Conference, Queen's University Belfast, September 15-17.

OECD. 2013. “Asian countries top OECD's latest PISA survey on state of global education." OECD, December 3. http://www.oecd.org/education/asian-countries-topoecd-s-latestpisa-survey-on-state-of-global-education.htm

Okihiro, G. 1994. Margins and Mainstreams: Asians in American History and Culture. Seattle: University of Washington Press.

Owen, D. 1994. Chinese People and 'Other' Ethnic Minorities in Great Britain: Social and Economic Circumstances Warwick: Centre for Research in Ethnic Relations, University of Warwick.

Pang, M. 1999. "The employment situation of young Chinese adults in the British labour market." Personnel Review 28 (1-2): 41-57.

Parker, D. 1998. "Emerging British Chinese Identities: Issues and Problems." In The Last Half Century of Chinese Overseas, edited by Elizabeth Sinn, 91-114. Hong Kong: Hong Kong University Press. 
Parker, D. 2000. "The Chinese Takeaway and the Diasporic Habitus: Space, time and power geometrics.” In Un/settled Multiculturalisms: Diasporas, Entanglements, 'Transruptions', edited by Barnor Hesse, 73-95. London: Zed Books.

Pearson, A. 2011. "Why we all need a Tiger Mother", The Telegraph, January 13, http://www.telegraph.co.uk/education/8255804/Why-we-all-need-a-Tiger-Mother.html

Petre, J. 2014. "Minister tells schools to copy China - and ditch trendy teaching for 'chalk and talk': Teachers speaking in front of a class 'much more effective than independent learning"', Mail on Sunday, November 15.

http://www.dailymail.co.uk/news/article-2836240/Minister-tells-schools-copy-Chinaditch-trendy-teaching-chalk-talk-Teachers-speaking-class-effective-independentlearning.html\#ixzz3qzxmUEzT

Ran, A. 2001. "Travelling on Parallel tracks: Chinese parents and English teachers." Educational Research 43 (3): 311-328.

Reay, D. 1998. Class Work: Mothers' involvement in children's schooling. London: University College Press.

Reay, D. 2006. "The zombie stalking English schools: social lass and educational inequality." British Journal of Educational Studies 54 (3): 288-307. doi: 10.1111/j.1467-8527.2006.00351.x

Reay, D. and Ball, S. 1998. "Making their minds up: family dynamics of school choice." British Education Research Journal 28 (1): 5-19.

San Juan, Jr., E. 1999. "From the Immigrant Paradigm to Transformative Critique: Asians in the Late Capitalist United States." In Race, ethnicity, and nationality in the United States : toward the twenty-first century, edited by Paul Wong, 34-54. Boulder, CO: Westview Press. 
Shah B., C. Dwyer, and T. Modood. 2010. "Explaining Educational Achievement and Career Aspirations among Young British Pakistanis: Mobilizing 'Ethnic Capital'?" Sociology. 44 (6): 1109-1127. doi:10.1177/0038038510381606

Sham, S. and Woodrow, D. 1998. "Chinese children and their families in England." Research Papers in Education 13 (2): 203-226.

Shrake, E. 2010. “Cram Schools.” In Encyclopedia of Asian American Issues Today, Vol. 1, edited by Edith Wen-Chu Chen and Grace J. Yoo, 211-15. Santa Barbara, CA: ABC-CLIO, LLC.

Siraj-Blatchford, I. ed. 1993. 'Race', Gender and the Education of Teachers. Buckingham: Open University Press.

Sue, S. and S. Okazaki. 2009. “Asian-American Educational Achievements: A Phenomenon in Search of an Explanation.” Asian American Journal of Psychology S (1): 45-55. doi: 10.1037/1948-1985.S.1.45

Suzuki, B. H. 1977. "Education and the socialization of Asian Americans: A revisionist analysis of the model minority thesis." Amerasia Journal 4 (2): 23-51.

Suzuki, B. H. 1989. “Asian Americans as the 'Model Minority': Outdoing Whites? Or media hype? Change: The Magazine of Higher Learning." 21 (6): 13-19. doi:10.1080/00091383.1989.9937601

Taylor, M. 1987. Chinese Pupils in Britain. Berkshire: NFER-Nelson.

Thomas, T. 2015. "British Chinese people say racism against them is 'ignored'”, BBC Newsbeat, Jan 6. http://www.bbc.co.uk/newsbeat/article/30538929/british-chinesepeople-say-racism-against-them-is-ignored 
Tomlinson, M. 2008. “'The Degree is Not enough': Students' Perceptions of the Role of Higher Education Credentials for Graduate Work and Employability." British Journal of Sociology of Education 29 (1): 49-61 doi:10.1080/01425690701737457

Vincent, C. 2001. "Social class and parental agency." Journal of Education Policy 16 (4): 347-364.

Vincent, C. and S. Ball. 2001. "A Market in Love? Choosing Pre-school Childcare.” British Educational Research Journal 27 (5): 633-651.

Vincent, C. and S. Ball. 2006. Childcare, Choice and Class Practices: Middle Class Parents and their Children. London: Routlege.

Walkerdine, V. 1989. Counting Girls Out. London: Virago.

Walkerdine, V. 1990. Schoolgirl Fictions. London: Verso.

Walkerdine, V., H. Lucey, and J. Melody. 2001. Growing Up Girl. Psychosocial Explorations of Gender and Class. Basingstoke: Palgrave.

Weale, S. 2014. "Culture, not just curriculum', determines east Asian school success." The Guardian, September 10. http://www.theguardian.com/world/2014/oct/09/eastasian-school-success-culture-curriculum-teaching

Weale, S. 2015. "Chinese teachers bring the art of maths to English schools." The Guardian, March 13. http://www.theguardian.com/education/2015/mar/13/chineseteachers-bring-the-art-of-maths-to-english-schools

Weis, L. 2004. Class Reunion. New York: Routledge.

Willis, E. 1977. Learning to Labour: How Working Class Kids Get Working Class Jobs. Lexington, MA: Lexington Books. 
Wong, L. 1994. "Di(s)-secting and Dis(s)-closing 'Whiteness." Feminism \& Psychology 4 (1): 133-153.

Wood, M., J. Hales, S. Purdon, T. Sejersen, and O. Hayllar 2009. "A test for racial discrimination in recruitment practice in British cities. National Centre for Social Research.” Department for Work and Pensions, Research Report No 607.

Woodrow, D. and S. Sham. 2001. "Chinese pupils and their Learning Preferences, Race." Equity and Education , 4 (4):377-394.

Wong, B. 2015. "A blessing with a curse: model minority ethnic students and the construction of educational success." Oxford Review of Education 41 (6): 730-746 doi: $10.1080 / 03054985.2015 .1117970$

Yeh, D. 2014. "Contesting the 'model minority': racialization, youth culture and 'British Chinese'/‘Oriental' nights.” Ethnic and Racial Studies 37(7): 1197-1210. doi: $10.1080 / 01419870.2014 .859288$

Zhou, M. 2005. "Ethnicity as Social Capital: Community-based Institutions and Embedded Networks of Social Relations." In Ethnicity, Social Mobility and Public Policy: Comparing USA and UK, edited by Glenn C. Loury, Tariq Modood and Steven M. Teles, 131-59. Cambridge: Cambridge University Press.

Zhou, M. 2008. " The Ethnic System of Supplementary Education: Nonprofit and Forprofit Institutions in Los Angeles' Chinese Immigrant Community.' In Toward Positive Youth Development: Transforming Schools and Community Programs, edited by Marybeth Shinn and Hirokazu Yoshikawa, 229-51. New York: Oxford University Press.

Zhou, M. and S. Kim. 2006. "Community forces, social capital and educational achievement: the case of supplementary education in the Chinese and Korean communities." Harvard Educational Review 76(1), 1-29. 
Zhou, M. and X. Li. 2003. "Ethnic language schools and the development of supplementary education in the immigrant Chinese community in the United States." New Directions for Youth Development: understanding the social worlds of immigrant youth 100 (Winter): 57-73.

Zwysen, W. and S. Longhi. 2016. "Labour market disadvantage of ethnic minority British graduates: university choice, parental background or neighbourhood?” ISER Working Paper Series. No. 2016-02, Institute for Social and Economic Research, University of Essex. 